WellBeing International

WBI Studies Repository

$5-2010$

\title{
Short-Beaked Common Dolphin (Delphinus delphis) Occurrence in the Moray Firth, North-East Scotland
}

\author{
Kevin P. Robinson \\ Cetacean Research and Rescue Unit \\ Sonja Eisfeld \\ Cetacean Research and Rescue Unit \\ Marina Costa \\ Cetacean Research and Rescue Unit \\ Mark P. Simmonds \\ Whale and Dolphin Conservation Society
}

Follow this and additional works at: https://www.wellbeingintlstudiesrepository.org/acwp_ehlm

Part of the Animal Studies Commons, Environmental Studies Commons, and the Population Biology Commons

\section{Recommended Citation}

Robinson, K. P., Eisfeld, S. M., Costa, M., \& Simmonds, M. P. (2010). Short-beaked common dolphin (Delphinus delphis) occurrence in the Moray Firth, north-east Scotland. Marine Biodiversity Records, 3, e55.

This material is brought to you for free and open access by WellBeing International. It has been accepted for inclusion by an authorized administrator of the WBI Studies Repository. For more information, please contact wbisr-info@wellbeingintl.org.

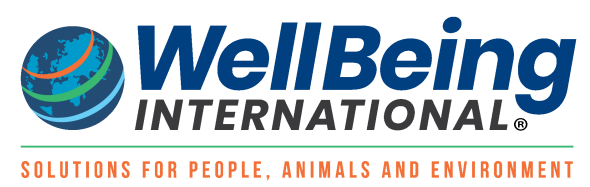




\title{
Short-Beaked Common Dolphin (Delphinus delphis) Occurrence in the Moray Firth, North- East Scotland
}

\author{
Kevin P. Robinson ${ }^{\dagger}$, Sonja M. Eisfeld ${ }^{\dagger, \ddagger},{\text { Marina } \text { Costa }^{\dagger} \text {, and Mark P. Simmonds }}^{\ddagger}$ \\ ${ }^{\dagger}$ Cetacean Research \& Rescue Unit \\ ${ }^{\ddagger}$ Whale \& Dolphin Conservation Society
}

\section{$\underline{\text { KEYWORDS }}$}

common dolphins, distribution, water temperature, Moray Firth, North Sea, range expansion, climate change, conservation management

\section{$\underline{\text { ABSTRACT }}$}

The short-beaked common dolphin (Delphinus delphis) is regarded as notably rare or absent from the northern North Sea, but recent evidence suggests a rising frequency of the species in these waters with increasing regional sea temperatures. The following paper documents the presence of $D$. delphis in the Moray Firth in north-east Scotland and provides the first evidence for the sustained occurrence of these delphinids in this region during the warmer summer months at least. Sightings were collated during systematic surveys of the outer Moray Firth between 2001 and 2009 by independent research teams from the CRRU and WDCS. A total of 13 encounters (with group sizes ranging from 2 to 450+ animals) were recorded with the species across this period, the first of which was in June 2006, with annual encounters being logged thereafter between the months of May and August from 2007 to 2009 inclusive. The animals were recorded in water depths of 51 to $209 \mathrm{~m}$ (mean depth: 88.6 $6 \pm 42.2 \mathrm{~m}$ ) and at a distance from shore of 5 to $32 \mathrm{~km}$ (mean distance: 16.6 $\pm 8.0 \mathrm{k} \mathrm{m}$ ). New born calves were observed in June and July, and photographic recaptures of identifiable 'marked' adults were determined in 2009. The consistent presence of common dolphins in the outer firth post 2005 and the recapture of recognizable individuals suggest a comparatively recent colonization of these waters by the species over a relatively short period of time. The impacts resulting from such a range expansion upon the existing cetacean community and the subsequent implications for management are discussed.

Between the months of May and October, the short-beaked common dolphin (Delphinus delphis Linnaeus, 1758) is one of the most abundant species of delphinid in British and Irish waters (Hammond et al., 2002; MacLeod et al., 2008). According to distribution maps by Reid et al. (2003), the shelf waters around the United Kingdom and Ireland comprise the northernmost limit for this species in the eastern North Atlantic. However, D. delphis is one of 30 warmer-water, neritic marine animals predicted to expand its geographical range in response to global climate change (MacLeod, 2009), and current evidence 
suggests an increased occurrence in northern UK and Irish waters with increasing regional sea temperatures (e.g. MacLeod et al., 2005; Weir et al., 2009; D. Wall, personal communication). Whether this implies local or wide scale changes in the distribution of the species remains unclear, but recent sightings (e.g. MacLeod et al., 2007a; C.R. Weir, personal communication) and incidental strandings (R.J. Reid, unpublished data) from the northern North Sea region certainly seem to corroborate the latter.

The present paper provides the first evidence for the recent occurrence of $D$. delphis in the Moray Firth in north-east Scotland $\left(57^{\circ} 41^{\prime} \mathrm{N} 02^{\circ} 20^{\prime} \mathrm{W}\right)$-a 5230 square kilometre coastal embayment within the northwestern North Sea (Figure 1). Sightings were collected during systematic boat surveys in the 'outer' Moray Firth by independent research teams from the Cetacean Research \& Rescue Unit (CRRU) and Whale \& Dolphin Conservation Society (WDCS). CRRU surveys were conducted annually between May and October in the southern region of the outer firth from 2001 to 2009, whilst WDCS carried out broaderscale surveys of the area (as shown in Figure 1) at variable intervals between February and November 2005 to 2009 (see Robinson et al., 2007, 2009; Eisfeld et al., 2009 for respective methodologies). The combined survey effort and sightings data from this undertaking are presented in Table 1.

Fig. 1. Map of the Moray Firth study site showing the distribution of common dolphin sightings with respect to the survey areas covered by the CRRU and WDCS research teams respectively. The CRRU effort was essentially restricted to a $1280 \mathrm{~km}^{2}$ area of the outer southern firth (as defined by the shaded boxes), whereas WDCS conducted a broader scale effort throughout the larger outer firth region as illustrated by all the boxes, un-shaded and shaded alike (total WDCS survey area $3696 \mathrm{~km}^{2}$ ). All sightings were recorded between the months of May and August from 2006 to 2009 inclusive.

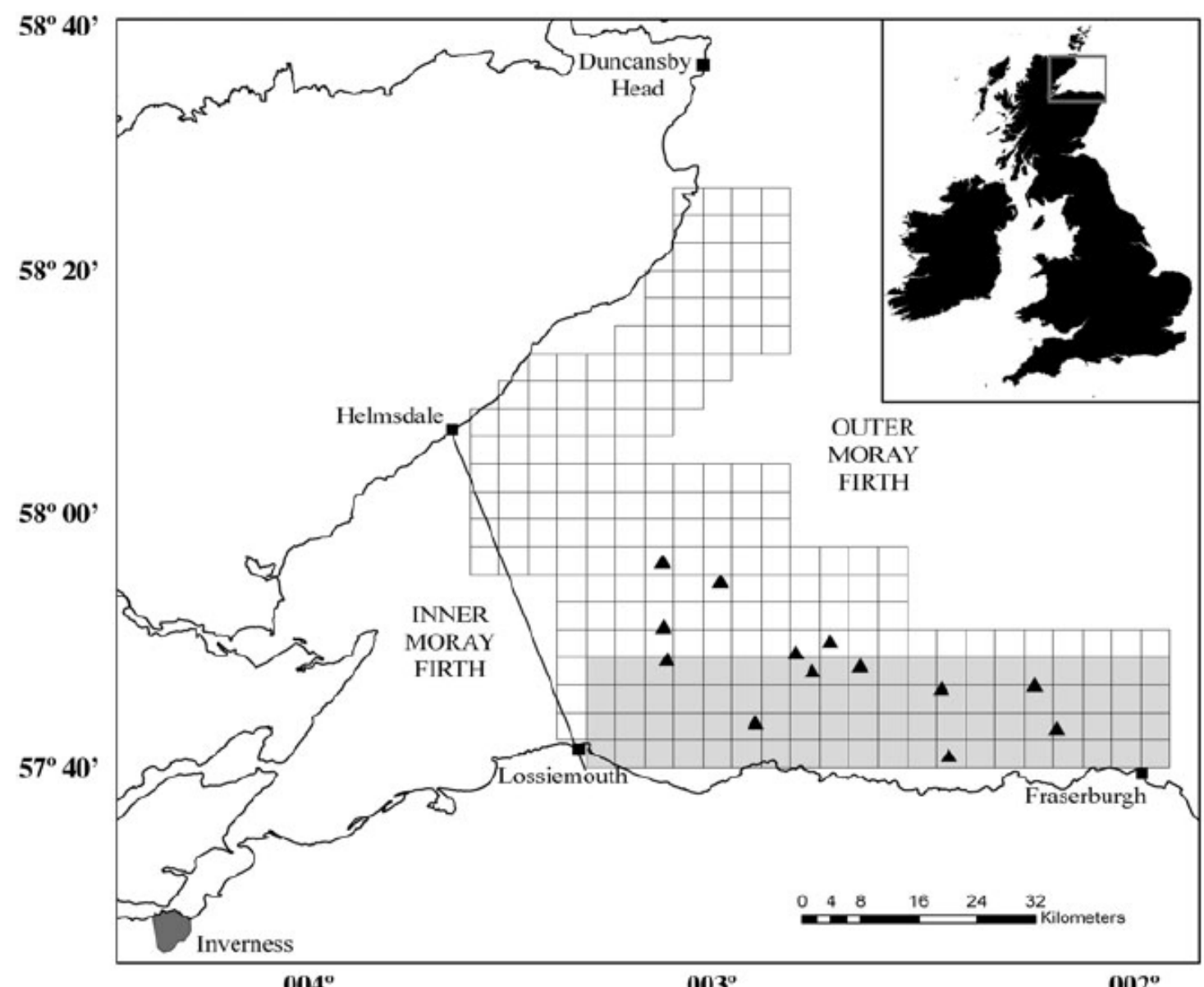

$004^{\circ}$

$003^{\circ}$

$002^{\circ}$ 
Table 1. Showing the combined CRRU/WDCS annual survey effort in the outer Moray Firth from 2001 to 2009 along with the number of $D$. delphis encounters recorded, the estimated number of animals sighted and the respective abundance of dolphins (number of animals/km) determined for each survey year.

\begin{tabular}{|ccccc|}
\hline Year & Survey effort $\mathbf{( k m )}$ & $\begin{array}{c}\text { Number of } \\
\text { encounters }\end{array}$ & $\begin{array}{c}\text { Total number of } \\
\text { animals sighted }\end{array}$ & Abundance \\
\hline 2001 & 405.95 & 0 & 0 & 0.0000 \\
2002 & 1101.00 & 0 & 0 & 0.0000 \\
2003 & 817.35 & 0 & 0 & 0.0000 \\
2004 & 587.50 & 0 & 0 & 0.0000 \\
2005 & 2260.32 & 0 & 0 & 0.0000 \\
2006 & 2591.72 & 4 & 177 & 0.0683 \\
2007 & 1808.23 & 3 & 337 & 0.1864 \\
2008 & 3397.69 & 4 & 54 & 0.0159 \\
2009 & 3532.45 & 2 & $650+$ & 0.1840 \\
Total & $16,502.22$ & 13 & $1218+$ & 0.0738 \\
\hline
\end{tabular}

Fig. 2. Photographs of $D$. delphis recorded by the research teams: (A) shows a 2.19 m deceased adult male recovered by the CRRU veterinary team from Rattray Head, south of Fraserburgh, in May 2005; (B) and (C) show common dolphins sighted during two separate boat encounters in the outer Moray Firth study area. The largest school encountered during the investigation was with an estimated $450+$ animals on 22 June 2009 (photographs: Kevin Robinson and Pascal Kriwy/CRRU).

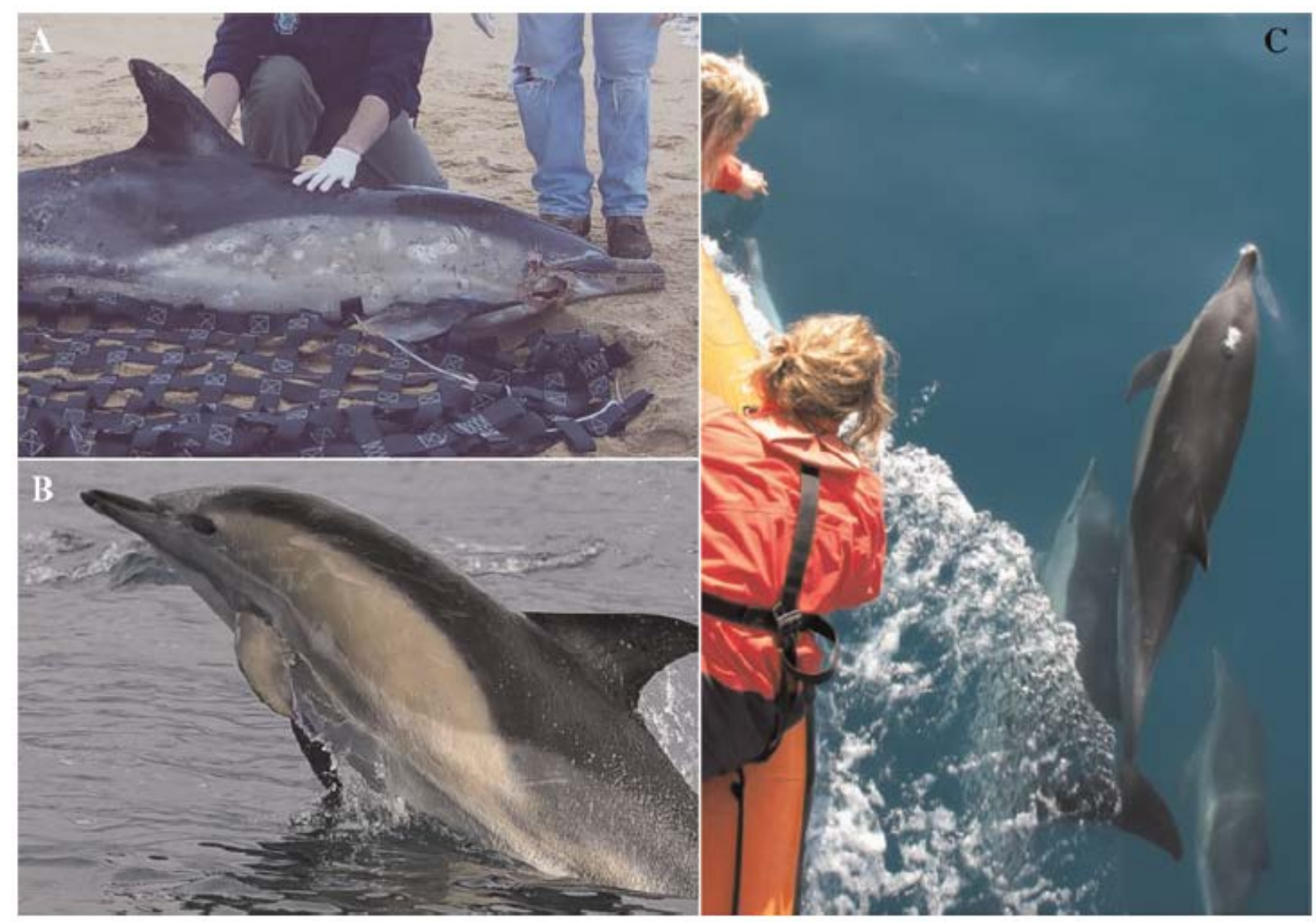


Fig. 3. Photographs showing new born (neonatal) common dolphin calves in the Moray Firth study area recorded in June and July 2009; note the very small size and discernible foetal folds of each of the youngsters in these images (photographs: Pascal Kriwy and Marina Costa/CRRU).

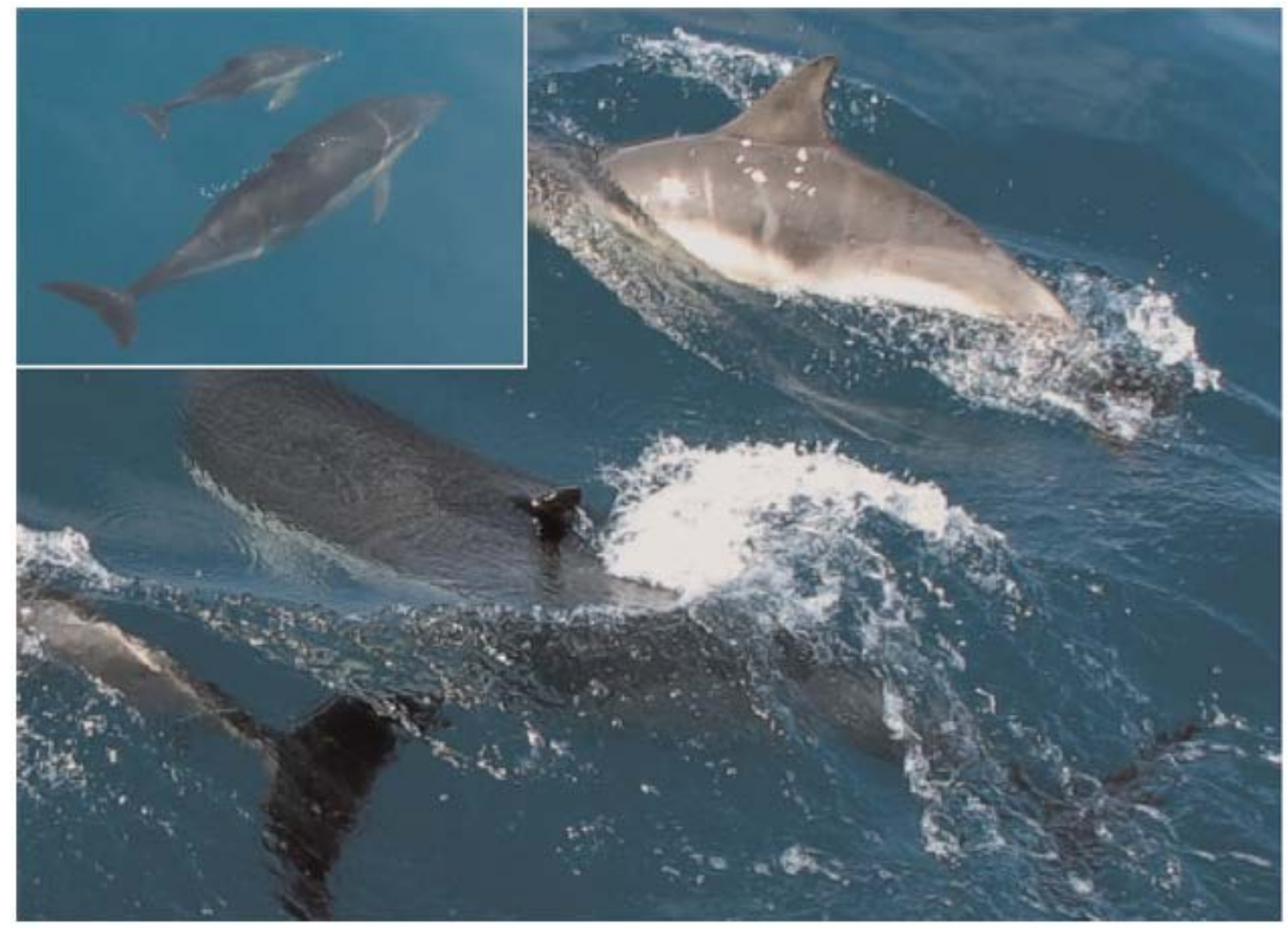

Further to several known strandings of $D$. delphis along the Moray Firth coastline (R.J. Reid, personal communication) (Figure 2A), the first live sighting of the species during the survey period (commencing in 2001) was recorded on 15 June 2006 during an encounter with approximately 75 animals. An additional three sightings were further reported in August 2006 with smaller groups of up to 40 animals (C.R. Weir, personal communication). Then in 2007, encounters were made on three separate occasions in June and July, one of which comprised over 300 dolphins. Encounters with several smaller groups (from 2 to 45 animals) were made again the following year in May and August, and a single animal was also confirmed in early November 2008 in Fraserburgh harbour (K.P. Robinson, personal observation)-this dolphin eventually made its way back out to sea. In 2009, sightings were further recorded in June and July with sizeable groups of $450+$ and $200+$ animals (Figure 2B \& C respectively). In summary, a total of 13 sightings (with group sizes ranging from 2 to 450+ animals) were cooperatively recorded by the CRRU/WDCS research teams between May and August 2006 to 2009, with an annual abundance of 0.0159 to 0.1864 animals per $\mathrm{km}$ (Table 1). Encounters were made at water depths from 51 to $209 \mathrm{~m}$ (mean depth: $88.6+42.2 \mathrm{~m}$ ) and at a distance from shore of 5 to $32 \mathrm{~km}$ (mean distance: $16.6+8.0 \mathrm{~km}$ ). New born calves were recorded in June 2007 and June and July 2009 (Figure 3). In addition, photographic recaptures were obtained of 17 'marked adults during 2009 (from a total of 86 identified individuals), suggesting a sustained occurrence of these animals within the Moray Firth study area, during the summer months at least. 
With few historical sightings and just a handful of incidental stranding records, the short-beaked common dolphin is, not surprisingly, listed as rare or notably absent from the northern North Sea (Reid et al., 2003; MacLeod et al., 2008; Figure 2). Accordingly, the regular occurrence of the species in the outer Moray Firth post-2005 described here, suggests a comparatively recent colonization of these northern waters over a relatively short period of time. Similar observations of escalating $D$. delphis occurrence along the west coast of Scotland have also been described by MacLeod et al. (2005) and Weir et al. (2009), with rising sea temperatures having been proposed as the most plausible explanation for this phenomenon (e.g. MacLeod et al., 2008). Furthermore, studies in the Bay of Biscay have noted a considerable decline in the species over the past few years (T. Brereton/Biscay Dolphin Research Programme, unpublished data) which might be significant with respect to the present observations in northern Scotland. Whether these distributional shifts are coincidental or related remains unclear. Yet it seems improbable that a potential range expansion by these delphinids into the northern North Sea is the result of increasing population size.

In fact the evidence suggests that common dolphins can react rapidly to changes in water temperature and adjust their distribution accordingly (MacLeod et al., 2007b;MacLeod, 2009). Moreover, historical strandings data infer that a similar, sustained expansion into the British North Sea may have occurred during a separate warm-water period in the 1930s to 1950s (Bakker \& Smeenk, 1990, MacLeod et al., in preparation). Whatever the underlying mechanism, however, the occurrence of short-beaked common dolphins in our northern shelf waters is clearly increasing, and this will inevitably have implications for existing cetacean communities and for conservation management strategies alike. New additions to the cetacean community in a particular region might conceivably lead to unexpected competition between sympatric species for common prey or essential habitat (Robinson et al., 2007; Weir et al., 2009), whilst range changes may result in unexpected, and therefore unplanned, interactions with human activities (Alter et al., 2010). Common dolphins are particularly vulnerable to by-catch, for example (de Boer et al., 2008; Murphy et al., 2009), and animals progressing north may begin to interact with North Sea fisheries where there was previously no problem and therefore few or no mitigating measures currently exist to address this. Furthermore, as range expansion into new areas occurs, a simultaneous decline in numbers may be seen in parts of the original range as the species re-distributes itself, which might incorrectly be attributed to negative human impacts such as over-fishing, direct disturbance or habitat degradation; although rising sea temperature resulting in the shifting demographics of target prey could also be attributed to anthropogenic effects as well. Consequently, changes in the fidelity, diversity and behaviour of these marine mega-fauna and their communities must be interpreted with care.

The conservation management of whales and dolphins inevitably requires a detailed knowledge of their distribution, abundance and the effects of anthropogenic activities upon their populations in order to better understand and protect them. For short-beaked common dolphins in the eastern North Atlantic, however, very little population-level information is currently available at this time (Murphy et al., 2009). The movements and habitat preferences exhibited by these delphinids in our UK shelf waters are also unquestionably complex and dynamic-driven by a multitude of interactive environmental factors, biological requirements and behavioural patterns (MacLeod, 2001; Murphy, 2004; de Boer et al., 2008; Weir et al., 2009). As such, present and ongoing studies on the abundance, diet, mortality rates and reproductive biology of $D$. delphis will ultimately shed light on the cross-sectional life history of the species, crucial to management directives for the conservation, welfare and protection of future generations. 


\section{ACKNOWLEDGEMENTS}

WDCS and the CRRU express their thanks to the numerous volunteers and staff that assisted with boat survey work between 2001 and 2009. CRRU surveys were carried out under licence from Scottish Natural Heritage and largely supported by the Earthwatch Institute (Europe) and Care for the Wild international, with additional funding from Ecovolunteer, Ecocorps Scotland, Advocates for Animals and the British Ecological Society. WDCS would like to thank the skippers and crew of the 'White Horse', 'Gemini Explorer' and 'Gemini Endeavour' (Chris, Davey, Iris and George) and the BBC Wildlife Fund for financial support in 2008 and 2009. Incidental strandings data are gratefully acknowledged from Bob Reid at the Scottish Agricultural College, Inverness.

\section{REFERENCES}

Alter S.E., Simmonds M.P. and Brandon J.R. (2010) Forecasting the consequences of climate-driven shifts in human behaviour on cetaceans. Marine Policy (in press) doi: 10.1016/j.marpool.2010.01.026

Bakker J. and Smeenk C. (1990) Dolphins on the Dutch coast: an analysis of stranding records. Lutra 33, 190-191.

de Boer M.N., Leaper R., Keith S. and Simmonds M.P. (2008) Winter abundance estimates for the common dolphin (Delphinus delphis) in the western approaches of the English Channel and the effect of responsive movement. Journal of Marine Animals and Their Ecology 1, 15-21.

Eisfeld S.M., Keith S., Pope A., Still D., Dolman S.J. and Simmonds M.P. (2009) Outer Moray Firth Cetacean Research 2008 Project Report for the BBC Wildlife Fund. Chippenham: Whale and Dolphin Conservation Society, 23 pp. (available from www.wdcs.org).

Hammond P.S., Berggren P., Benke H., Borchers D.L., Collet A., Heide-Jørgensen M.P., Heimlich S., Hiby A.R., Leopold M.F. and Øien N. (2002) Abundance of harbour porpoise and other cetaceans in the North Sea and adjacent waters. Journal of Applied Ecology 39, 361-376.

Macleod K. (2001) The spatial and temporal distribution of cetaceans off the west coast of Scotland in relation to environmental factors. PhD thesis. University of Greenwich, London, UK.

MacLeod C.D. (2009). Global climate change, range changes and potential implications for the conservation of marine cetaceans: a review and synthesis. Endangered Species Research 7, 125-136.

MacLeod C.D., Bannon S.M., Pierce G.J., Schweder C., Learmonth J.A., Reid R.J. and Herman J.S. (2005) Climate change and the cetacean community of north-west Scotland. Biological Conservation 124, 477-483.

MacLeod C.D., Hepworth K. and Hay I. (2007a) Northern North Sea cetacean ferry surveys (NORCET): an analysis of cetacean information collected in the first five years (2002-2006). Internal Report, Aberdeen, UK, 13 pp. (available from c.d.macleod@abdn.ac.uk).

MacLeod C.D., Weir C.R., Pierpoint C. and Harland E. (2007b) The habitat preferences of marine mammals west of Scotland (UK). Journal of the Marine Biological Association of the United Kingdom 87, 157-164.

MacLeod C.D., Weir C.R., Santos M.B. and Dunn T.E. (2008) Temperature-based summer habitat partitioning between white-beaked and common dolphins around the United Kingdom and Republic of Ireland. Journal of the Marine Biological Association of the United Kingdom 88, 11931198.

Murphy S. (2004) The biology and ecology of the common dolphin Delphinus delphis in the North-east Atlantic. PhD thesis. University College Cork, Ireland. 
Murphy S., Winship A., Dabin W., Jepson P.D., Deaville R., Reid R.J., Spurrier C., Rogan E., López A., González A.F., Read F.L., Addink M., Silva M., Ridoux V., Learmonth J.A., Pierce G.J. and Northridge S.P. (2009) Importance of biological parameters in assessing the status of Delphinus delphis. Marine Ecology Progress Series 388, 273-291.

Reid J.B., Evans P.G.H. and Northridge S.P. (2003) Atlas of cetacean distribution in north-west European waters. Peterborough: Joint Nature Conservation Committee.

Robinson K.P., Baumgartner N., Eisfeld S.M., Clark N.M., Culloch R.M., Haskins G.N., Zapponi L., Whaley A.R., Weare J.S. and Tetley M.J. (2007) The summer distribution and occurrence of cetaceans in the coastal waters of the outer southern Moray Firth in northeast Scotland (UK). Lutra 50, 19-30.

Robinson K.P., Tetley M.J. and Mitchelson-Jacob E.G. (2009) The distribution and habitat use of coastally occurring minke whales (Balaenoptera acutorostrata) in northeast Scotland. Journal of Coastal Conservation 13, 39-48.

Weir C.R., MacLeod C.D. and Calderan S.V. (2009) Fine-scale habitat selection by white-beaked and common dolphins in the Minch (Scotland, UK): evidence for interspecific competition or coexistence? Journal of the Marine Biological Association of the United Kingdom 89, 951-960. 